\title{
IDENTIFICATION OF THE BINDING SITE FOR PLASMINOGEN KRINGLE 5 IN THE $\alpha$-CHAIN OF FIBRIN(OGEN) D-FRAGMENT
}

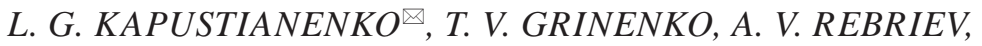 \\ O. I. YUSOVA, A. A. TYKHOMYROV
}

Palladin Institute of Biochemistry, National Academy of Sciences of Ukraine, Kyiv;

凶e-mail: kapustyanenko@biochem.kiev.ua

Received: 17 May 2020; Accepted: 30 June 2020

The interaction of the fifth kringle of Glu-plasminogen with fibrin triggers activation and initiation of fibrinolysis, yet the site on fibrin that binds kringle 5 remains unknown. The aim of our work was to determine an amino acid sequence in the D-fragment of fibrin(ogen) molecule, which is complementary to the lysine-binding site (LBS) in kringle 5. We studied the interaction between kringle 5 of plasminogen with polypeptide chains of the D-fragments of fibrin and cyanogen bromide fragments FCB-2 and $t$-NDSK and showed that kringle 5 bound specifically to $\alpha$-and $\gamma$-chains of the D-fragment and the $\alpha$-chain of FCB-2. Tryptic peptides of D-fragment $\alpha$-chain were obtained, separated by their ability to bind with the immobilized kringle 5, and then all studied peptides were characterized by MALDI-TOF analysis. The critical amino acid residues of the $\alpha$-chain of D-fragment, which provide its interaction with kringle 5, turned out to be $\alpha 171 \mathrm{Arg}$ and/or a176Lys. The binding site of Glu-plasminogen complementary to the LBS of kringle 5 is located within Aa168Ala-183Lys, a sequence in a weakly structured loop between two supercoils in the $\alpha$-chain of the Dfragment of the fibrin(ogen) molecule.

Ke y w o rds: plasminogen, kringle 5, fibrin(ogen), binding site, $\alpha$-chain of fibrin D-fragment, fibrinolysis.

\section{Introduction}

Fibrin is the main component of blood clots, which are formed to stop and prevent blood loss after vessel damage. Also, fibrin clot formation plays the primary role in the development of life-threatening thrombotic conditions and vascular pathologies, such as ischemic heart disease, atherosclerosis, myocardial infarction, stroke, etc. Therefore, investigation of the molecular mechanisms of protein interactions related to fibrin degradation has vital clinical implications. Proteolytic enzyme plasmin (EC 3.4.21.7) is the key fibrinolytic proteinase responsible for clot degradation in vivo. Plasmin is derived from circulating non-active zymogen plasminogen. The interaction between plasminogen and tissue activator with polymeric fibrin localizes plasmin generation on the surface of the fibrin clot, and therefore makes possible the selective fibrin hydrolysis and keeps plasmin protected from the plasma inhibitor, $\alpha$-2-antiplasmin [1,2].

Glu-plasminogen is the native form of plasminogen, which has a glutamate residue at the NH2terminus. It consists of several domains: the N-terminal domain, five sequential homologous kringle domains (K1, K2, K3, K4, and K5) and the proteinase domain. Lysine-binding sites (LBSs) of kringle domains allow the interaction of plasminogen with various proteins and receptors [3-6]. Glu-plasminogen exists in the closed conformation in plasma, it is stabilized by intramolecular interactions of the $\mathrm{N}$ terminal domain with the K5 [7]. When K5 binds to ligands, Glu-plasminogen acquires open conformation $[8,9]$. Limited proteolysis of plasminogen by plasmin can detach the $\mathrm{N}$-terminal domain from Glu-plasminogen molecule resulting in the partially degraded Lys-plasminogen, which has an open con-

(c) 2020 Kapustianenko L. G. et al. This is an open-access article distributed under the terms of the Creative Commons Attribution License, which permits unrestricted use, distribution, and reproduction in any medium, provided the original author and source are credited. 
formation. In healthy individuals, Lys-plasminogen is not detected in blood plasma. The transformation of Glu-plasminogen into the partially degraded form in vivo may occur on the cell surface $[10,11]$ or on the fibrin network during clot hydrolysis [12]. Plasminogen activation by endogenous activators (e. g. tissue plasminogen activator or urokinase) occurs by cleavage of the Arg561-Val562 peptide bond, resulting in the formation of the active center and two-chain molecule of plasmin. An activation loop, containing the Arg561-Val562 peptide bond, is located between $\mathrm{K} 5$ and the proteinase domain. In the closed conformation of Glu-plasminogen, it is shielded by a connector, which holds together $\mathrm{K} 3$ and $\mathrm{K} 4$, and is presented to the activator during the transition of zymogen into the open conformation.

Both Glu- and Lys-forms of plasminogen specifically bind to fibrin. Adsorption of Lys-plasminogen is inhibited by 6-aminohexanoic acid (6-AHA) at concentrations saturating the high-affinity ligand binding site located in the K1, while adsorption of Glu-plasminogen is suppressed at the saturation of the low-affinity ligand binding sites located in the K4 and K5. The fact that Glu-plasminogen interaction with fibrin is mediated by the $\mathrm{K} 5$ is confirmed by the data that the mini-plasminogen and the kringle fragment 1-5 inhibit, while kringle fragment 1-3 does not affect the binding of Glu-plasminogen to fibrin $[13,14]$. Isolated $\mathrm{K} 5$ exerts an inhibitory effect on desAB fibrin hydrolysis upon Glu-plasminogen activation by tissue activator [15]. The contribution of the LBS of K5 to interaction with fibrin leads to dissociation of the electrostatic bond between this site and the N-terminal domain, causing Glu-plasminogen to adapt open conformation, which provides its activation by the tissue activator and initiates fibrin hydrolysis.

Polymeric fibrin is formed from fibrinogen under the action of thrombin. Structural rearrangements occurring in the D-regions of fibrin(ogen) during polymerization lead to exposure of plasminogen and tissue activator binding sites [2]. It was shown that the binding site for plasminogen is localized within 148-160 amino acid residues sequence of the A $\alpha$-chain, but it is unclear with which kringle do- main it interacts. A synthetic peptide corresponding to the Aa148-160 sequence in fibrin(ogen) stimulates activation of plasminogen by tissue activator and does not affect activation of mini-plasminogen [16]. A thermostable region of the D fragment (TSD, $28 \mathrm{kDa}$ ), whose $\alpha$-chain encompasses a $148-160$ amino acid residues sequence, has one plasminogen-binding site of high affinity for Lys-plasminogen $\left(K_{d}=0.44 \mu \mathrm{M}\right)$, interacts with the kringle K1-3 and does not bind $\mathrm{K} 4$ and mini-plasminogen [17]. These data convincingly show that the plasminogenbinding site localized in the 148-160 sequence of the D-fragment A $\alpha$-chain is complementary to the LBS in kringle fragment 1-3 of plasminogen molecule. Given that the K5-mediated Glu-plasminogen interaction with fibrin triggers the process of zymogen activation and fibrinolysis initiation, the determination of the binding site for K5 in the fibrin molecule is of essential importance to understand the molecular mechanisms of fibrinolysis and to search ways to regulate this process. Thus, the aim of our study was to identify the binding site for K5 LBS of Glu-plasminogen in the D-fragment of fibrin(ogen) molecule.

\section{Materials and Methods}

Fibrinogen was isolated from donor blood plasma by fractional salting out with sodium sulfate [18]. Fibrin, covalently crosslinked by coagulation factor XIIIa, was obtained by thrombin-induced polymerization of fibrinogen in the presence of calcium ions $(25 \mathrm{mM})$ [19]. Non-crosslinked fibrin was obtained from thrombin-activated fibrinogen in the presence of 6-AHA and para-hydroxymercuribenzoate [20]. DD-fragment was obtained by plasmin hydrolysis of the crosslinked fibrin in the presence of $5 \mathrm{mM} \mathrm{Ca} 2+$ [19]. D-fragment was produced by plasmin hydrolysis of non-crosslinked fibrin [21]. The hydrolysis reaction was stopped by 6-AHA in the presence of EDTA. FCB-2 and t-NDSK were obtained by cyanogen bromide cleavage of fibrin [22].

Glu-plasminogen was purified from donor blood plasma on lysine-Sepharose 4B (GE Healthcare BioScience, Uppsala, Sweden) [23]. Mini-plasminogen (Val442-plasminogen) was produced by

\footnotetext{
Abbreviations: desAB fibrin - fibrin containing neither A nor B fibrinopeptides; t-NDSK - thrombin-treated N-terminal disulfide knot of fibrin; FCB-2 - cyanogen bromide fragment of fibrin(ogen) consisting of fibrinogen chain fragments A 148 -208, B $3191-224,225-242,243-305$ and $\gamma 95-265$, linked by disulfide bonds; D-fragment - one of the two identical terminal regions of fibrinogen; DD-fragment - two identical terminal regions of adjacent fibrin molecules, covalently cross-linked by factor XIIIa.
} 
limited hydrolysis of the plasminogen by elastase (EC 3.4.21.36) (Sigma, St. Louis, USA) with further gel-filtration on Toyopearl HW-50 Fine Grade (TOYO SODA Manufacturing Co., Ltd., Tokyo, Japan) and chromatography on lysine-Sepharose 4B [24]. Degradation of the mini-plasminogen was done using pepsin (EC 3.4.23.1) (Sigma, St. Louis, USA).

K5 was obtained from pepsin hydrolysate of mini-plasminogen on AH-Sepharose 4B [24]. Immobilization of $\mathrm{K} 5$ onto BrCN-activated Sepharose 4B was carried out as described elsewhere [25]. Polyclonal antibodies were obtained from immunoserum of K5-immunized rabbits by chromatography on K5Sepharose 4B [25].

Purity of the obtained proteins was determined electrophoretically in 10\% PAGE with $0.1 \%$ SDS [26] using molecular mass markers of 10-260 kDa (Spectra Multicolor Broad Range Protein Ladder, Fermentas, Lithuania). Protein concentration was calculated by the optical density of solutions at 280 and $320 \mathrm{~nm}$ using their $\mathrm{E}^{280}{ }_{1 \%}$ and molecular masses. All reagents were at least chemically pure grade.

Determination of proteins able to specifically bind K5 was done by Western-blotting [27] using polyclonal antibodies to K5. Proteins and their polypeptide chains, reduced by $\beta$-mercaptoethanol, were separated by electrophoresis in 10\% PAGE with $0.1 \%$ SDS and transferred from the gel onto nitrocellulose membrane with $0.45 \mu \mathrm{m}$ pore size (GVS North America/Sigma, St. Louis, USA). Membrane was blocked by $3.5 \%$ solution of non-fat skim milk (BioRad, Hercules, USA) in phosphate buffer saline (PBS). K5 (20 $\mu \mathrm{g} / \mathrm{ml}$ in PBS with 0.05\% Tween-20, PBST) was bound to proteins, adsorbed on the nitrocellulose membrane, during 2 hours at $37^{\circ} \mathrm{C}$. In the next stage, the membrane was incubated with antibodies to $\mathrm{K} 5(5 \mu \mathrm{g} / \mathrm{ml}$ in PBST) for 1 hour at $37^{\circ} \mathrm{C}$. Then, the membrane was incubated with goat anti-rabbit IgG-HRP conjugate (Sigma, St. Louis, USA) in PBST for 1 hour at $37^{\circ} \mathrm{C}$. After every incubation stage, the membrane was thoroughly washed by PBST from non-specifically bound antibodies. Specific immunostaining was developed in 0.05\% 4-chloro-1-naphthol (Sigma, USA) solution in $0.05 \mathrm{M}$ potassium phosphate buffer ( $\mathrm{pH} 6.0$ ) with $0.06 \% \mathrm{H}_{2} \mathrm{O}_{2}$.

$\alpha$-Chains were obtained from the D-fragment of non-cross-linked fibrin by preparative electrophoresis in 10\% PAGE with 0.1\% SDS. To accomplish this, the disulfide bonds of the D-fragment were reduced by $5 \% \beta$-mercaptoethanol in PBS with $8 \mathrm{M}$ urea under argon atmosphere for $3 \mathrm{~h}$ at $37^{\circ} \mathrm{C}$. The
SH-groups were alkylated by 4-vinylpyridine (Sigma, USA) under argon atmosphere for $2 \mathrm{~h}$ at $20^{\circ} \mathrm{C}$ [28]. The proteins were precipitated by acetone and fractionated by electrophoresis. $\alpha$-chains fractions were eluted from the respective bands of the gel with $0.1 \%$ trifluoroacetic acid (TFA) and precipitated by acetone.

Trypsin hydrolysis of the $\alpha$-chains was performed as previously described [29]. The acetone pellet, which contained $\alpha$-chains, was dissolved in $0.1 \mathrm{M}$ ammonia-bicarbonate buffer, $\mathrm{pH} 9.5$ and incubated with trypsin (EC 3.4.21.4) (Applied Biosystems, Carlsbad, USA) at 1:25 enzyme : substrate mass ratio for $4 \mathrm{~h}$ at $37^{\circ} \mathrm{C}$ and for $16 \mathrm{~h}$ at $25^{\circ} \mathrm{C}$. Trypsin was inhibited by diisopropyl fluorophosphate (Sigma, St. Louis, USA), and the hydrolysate was dialyzed against $0.05 \mathrm{M}$ PBS.

Affinity chromatography of the tryptic peptides was performed on K5-Sepharose 4B [23]. $\alpha$-Chain tryptic hydrolysate $(0.3 \mathrm{mg}$ dissolved in the same buffer) was applied onto a $1.4 \mathrm{ml}$ column bearing $0.6 \mathrm{mg}$ of immobilized K5 and balanced with $0.05 \mathrm{M}$ PBS. Peptides not bound to K5 were washed out. The sorbent was then washed with PBS. Specifically bound to K5-Sepharose peptides were eluted with $0.25 \mathrm{M}$ 6-AHA in $0.05 \mathrm{M}$ Na-phosphate buffer ( $\mathrm{pH}$ 7.4). The amount of protein in the fractions was measured spectrophotometrically using $\mathrm{BCA}^{\mathrm{TM}}$ Protein Assay Kit (Thermo Fisher Scientific, Pittsburgh, USA) at $\lambda=570 \mathrm{~nm}$. Both fractions of tryptic peptides (bound to K5 and not bound) were dialyzed against $0.05 \mathrm{M}$ Na-phosphate buffer (pH 7.4) to remove 6-AHA and $\mathrm{NaCl}$ and concentrated on SpeedVac (Thermo Fisher Scientific, Waltham, USA). In total, $0.024 \mathrm{mg}$ of protein in $0.01 \mathrm{ml}$ solution bound to $\mathrm{K} 5$ was obtained by affinity chromatography, and $0.23 \mathrm{mg}$ of protein in $0.1 \mathrm{ml}$ solution appeared to be not bound.

The tryptic peptides were studied by MALDITOF using the Voyager DE PRO spectrometer (Applied Biosystems, Carlsbad, USA) in the positive ion mode, in the mass range $\mathrm{MH}+$ of 500 to $5000 \mathrm{kDa}$. We used reflex mode of time-of-flight detector of the mass-spectrometer with the applied voltage of $20 \mathrm{kV}$. Internal calibration was performed using matrix peaks $(\mathrm{MH}+666.0293)$ and autolyse peptides of trypsin $(\mathrm{MH}+2163.0566,2273.1599)$. H+matrix ionization of tryptic peptides was done using 3,5-dimethoxy-4-hydroxycinnamic acid (DHCA, Sigma, USA) under laser emission. DHCA concentration in the matrix reagent was $1 \mathrm{mg} / \mathrm{ml}$, reagent was dissolved in a solution of equal volumes of 
acetonitrile (Sigma, USA) and 0.1\% TFA acid. For analysis, $1 \mu \mathrm{l}$ of each sample (fractions of affinity bound and not bound to K5 tryptic peptides with $2.4 \mathrm{mg} / \mathrm{ml}$ and $2.3 \mathrm{mg} / \mathrm{ml}$ concentrations respectively) was mixed with $1 \mu \mathrm{l}$ of matrix reagent and transferred to the sample plate, then dried and analyzed. The mass spectrum data were treated using DataExplorer 4.1 (Applied Biosystems, Carlsbad, USA). We measured monoisotopic values of the protonated molecules, using the average of 4 to 10 mass spectrum data. The amino acid sequence of the tryptic peptides was determined using an online resource Peptide Mass Calculator (Expasy.org). The presented electrophoregrams and blotograms are typical for repeated experiments. The results of experiments, the permissible error of which did not exceed 5\% $(P<0.05)$ were included in the work. Graphic modeling was performed using the Internet resource Protein Data Bank (PDB) archive. The ribbon diagrams of D-fragment (PDB ID: 1FZC) and plasminogen K5 (PDB ID: 2KNF) are based on their crystal structure $[30,31]$.

\section{Results and Discussion}

We have recently shown that plasminogen fragments of K1-3 and K5 bind to different sites that are adjacent in the DD fragment of fibrin [32]. The known binding site for plasminogen located in the A $\alpha 148$-160 sequence of the D-region of fibrin(ogen), according to the literature, is complementary to the LBS of K1-3, while the binding site for K5 remains unknown. Binding of the isolated K5 to fibrin Dand DD-fragments and their polypeptide chains was investigated by means of immunoblotting to localize the region responsible for the K5-mediated interaction of Glu-plasminogen with fibrin. This approach reveals the binding sites on the linear fragments of the polypeptide chains. Fibrin fragments and their chains were separated by SDS-PAGE in the presence of $\beta$-mercaptoethanol for reducing disulfide bonds. Proteins were transferred from gel to a nitrocellulose membrane, which was then incubated with K5. The bound $\mathrm{K} 5$ was detected using monospecific polyclonal antibodies and visualized using anti-rabbit antibodies conjugated to horseradish peroxidase. The data presented in Fig. 1 show that K5 is specifically adsorbed to the DD-fragment of fibrin and the D-fragment obtained from non-cross-linked fibrin. K5 binds to $\alpha$-, $\gamma$ - and $\gamma \gamma$-chains but is not adsorbed on the $\beta$-chains of the fragments (Fig. 2). The results suggest that the interaction of plasminogen,

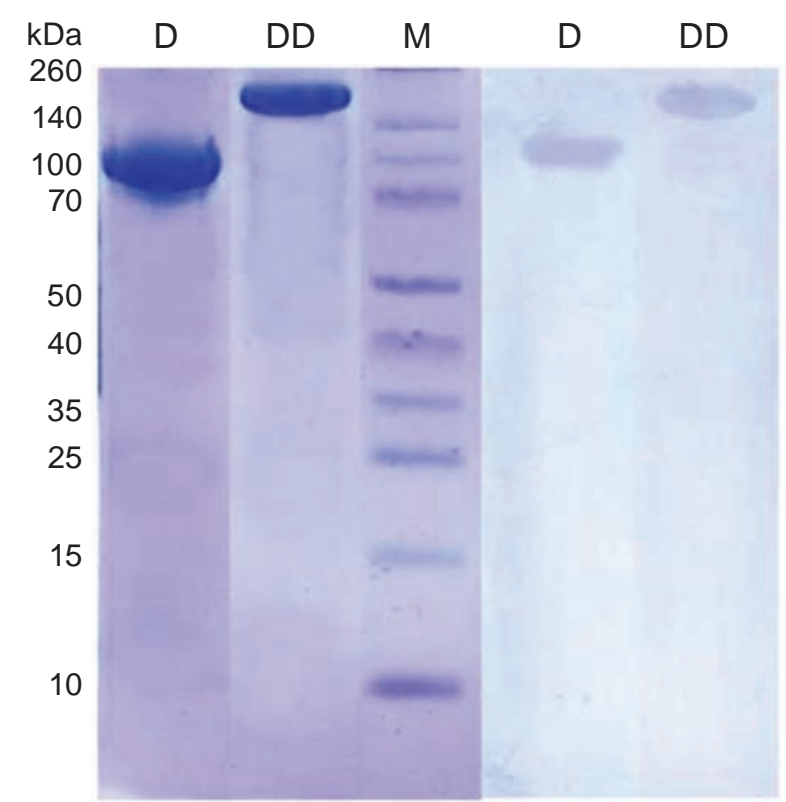

Fig. 1. Electrophoregram of the D-fragment of noncross-linked fibrin and DD-fragment of fibrin (left from markers). Western blot image of fragments, to which K5 binds (right from markers). M- molecular mass markers

mediated by the ligand-binding site of $\mathrm{K} 5$, can happen with complementary sites in the $\alpha$ - and $\gamma$-chains of the peripheral D-regions. Binding sites for $\mathrm{K} 5$ are absent in the $\beta$-chains of these fragments.

It is known that the cyanogen bromide fragment of fibrin(ogen) FCB-2 stimulates activation of Glu-plasminogen by tissue activator (e.g., it has binding sites for these proteins), while t-NDSK does not exhibit effector properties [33]. Subsequently, the interaction of $\mathrm{K} 5$ with the polypeptide chains of these fragments was investigated using an immunoblot, and t-NDSK was used as a negative control. The FCB-2 fragment consists of peptides of all three polypeptide chains of the D-fragment: $\alpha-5.9 \mathrm{kDa}$; $\beta-5.8 ; 4.3 ; 2.2 \mathrm{kDa}$ and $\gamma-21 \mathrm{kDa}$, which are interconnected by disulfide bonds. The fragment of the central part of the molecule, t-NDSK, has structural similarities with the E-fragment and consists of the following chains: $\alpha-3.5 \mathrm{kDa} ; \beta-9 \mathrm{kDa} ; \gamma-$ $10.5 \mathrm{kDa}$. Fig. 3 shows a scheme that illustrates location of the studied polypeptides in the structure of the fibrinogen molecule.

The SDS-PAGE of fragment FCB-2, reduced by $\beta$-mercaptoethanol, clearly shows two protein bands, one for the $\gamma$-chain $(21 \mathrm{kDa})$ and the other for a mix of $\alpha$ - and $\beta$-chains (5.9 and $5.8 \mathrm{kDa}$, respectively). Polypeptide chains of the t-NDSK frag- 


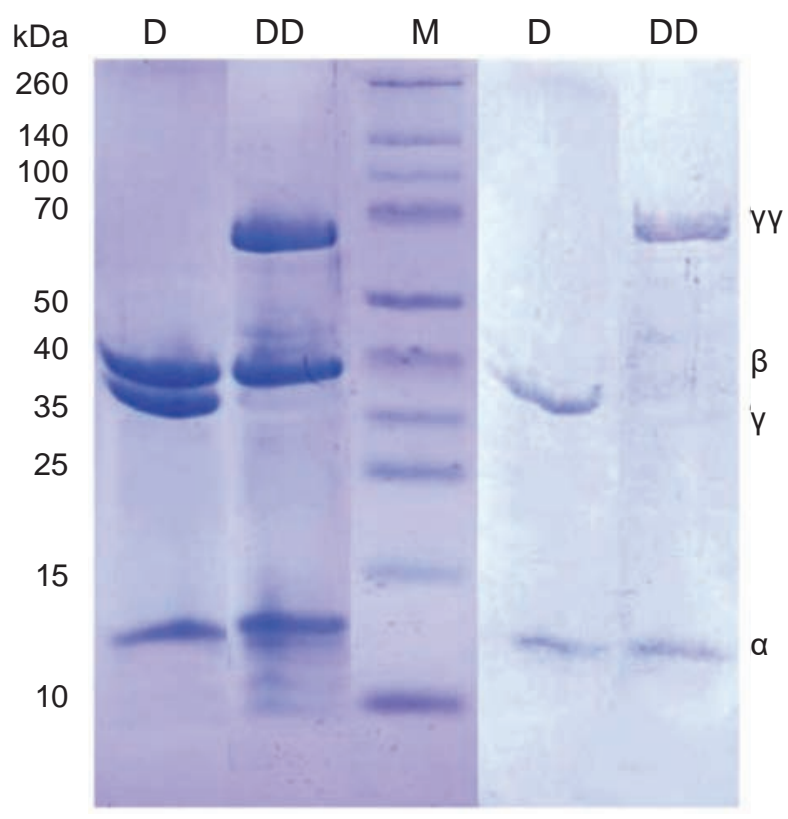

Fig. 2. Electrophoregram of polypeptide chains of $D$-fragment of non-cross-linked fibrin and DD fragment of fibrin (left from markers). Western blot image of polypeptide chains of the fragments, to which $K 5$ binds (right from markers). $M-$ molecular mass markers

ment are represented by two adjacent bands belong to $\beta$ - and $\gamma$-chains (9.0 and $10.5 \mathrm{kDa}$, respectively), and the $\alpha$-chain $(3.5 \mathrm{kDa})$ is not seen on the SDS PAGE (Fig. 4, $A$ ). The Western blot image (Fig. 4, $B$ ) shows the binding of $\mathrm{K} 5$ to polypeptide chains of the studied fragments. It is seen that $\mathrm{K} 5$ does not interact with the $\gamma$-chain of FCB-2, which consists of the amino acid residues $\gamma 95-265$, i.e. there is no binding site for plasminogen $\mathrm{K} 5$ within this polypeptide fragment in the D-fragment of the fibrin(ogen) molecule. Meanwhile, K5 interacts with the protein band, which includes the $\alpha$ - and $\beta$-chains of the FCB-2 fragment. As we have shown, K5 does not bind to the $\beta$-chains of the DD- and D-fragments. Therefore, the detected band, corresponding to the $\alpha$ - and $\beta$-chains, indicates the interaction of kringle 5 with the $\alpha$-chain of the FCB-2 fragment, represented by amino acid residues $\alpha 148-207$. Less intense staining of this band is due to the partial contribution of the $\beta$-chain. It should be noted that K 5 does not bind to any of the presented chains of the t-NDSK fragment (Fig. 4, B).

Absence of the cationic center is the key feature of the K5 ligand binding site, while the anionic center is represented by the canonical Asp516 and Asp518. During the study of K5 ligand specificity, it was shown that it has affinity to aminohexyl-, homoarginine- and guanidine-hexyl-Sepharose 4B and does not interact with arginine-Sepharose 4B, the ligand mimicking the $\mathrm{C}$-terminal arginine in proteins [34]. Therefore, the structural requirements of K5 ligand binding site are met by the lysyl or arginyl residues in the polypeptide chains of proteins.

The obtained data showing the lack of K5 interaction with the polypeptide chains of t-NDSK fragment and $\beta$-chains of DD- and D-fragments, which contain a certain amount of lysyl and arginyl residues, indicate that not all positively charged amino acid residues, exposed on linear fragments of polypeptide chains under experimental conditions, may serve as ligands for K5. Obviously, the site within the fibrin(ogen) molecule, complementary to the K5 ligand binding site, has a structure, that provides the necessary presentation of the side radical of lysine or arginine, the positive charge of which is not compensated by interactions with surrounding amino acid residues.

Thus, as a result of the conducted researches, the new information about localization of plasminogen kringle 5 binding sites in the polypeptide chains of the fibrin(ogen) D-regions has been obtained. It is shown that $\mathrm{K} 5$ specifically interacts with the $\alpha$-chains of D- and DD-fragments of fibrin, which

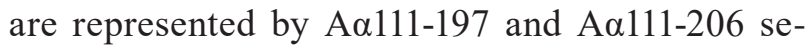
quences, respectively, as well as with the $\alpha$-chain of the cyanogen bromide fragment FCB-2, which is identical to the A $\alpha 148-207$ fragment of fibrin(ogen) molecule. A comparison of these fragments of the polypeptide chains allows one to assume that the K5 binding site is located in the polypeptide sequence A $\alpha 148-197$. Because the A $\alpha 148-160$ section is responsible for interaction with the K1-3 plasminogen fragment, the $\mathrm{K} 5$ binding site probably is located within the Aa160-197 sequence. This section of the $\alpha$-chain contains arginyl residues in the 162,167 , 171, and 197 positions and lysyl - in the 176, 183, and 191 positions, making them potential targets for $\mathrm{K} 5$ binding. It was shown that the $\gamma$-chain of the Dfragment also contains the $\mathrm{K} 5$ binding sites outside the sequence $\gamma 95-265$.

Taking into consideration that the binding sites for K1-3 and K5 in the fibrin DD-fragment are adjacent [32], further studies were aimed to explore more detailed localization of the K5 binding site in the $\alpha$-chain of D-fragments. To accomplish this, an isolated $\alpha$-chain was obtained from the $\mathrm{D}$-fragment of fibrin, tryptic peptides of the $\alpha$-chain were produced, 


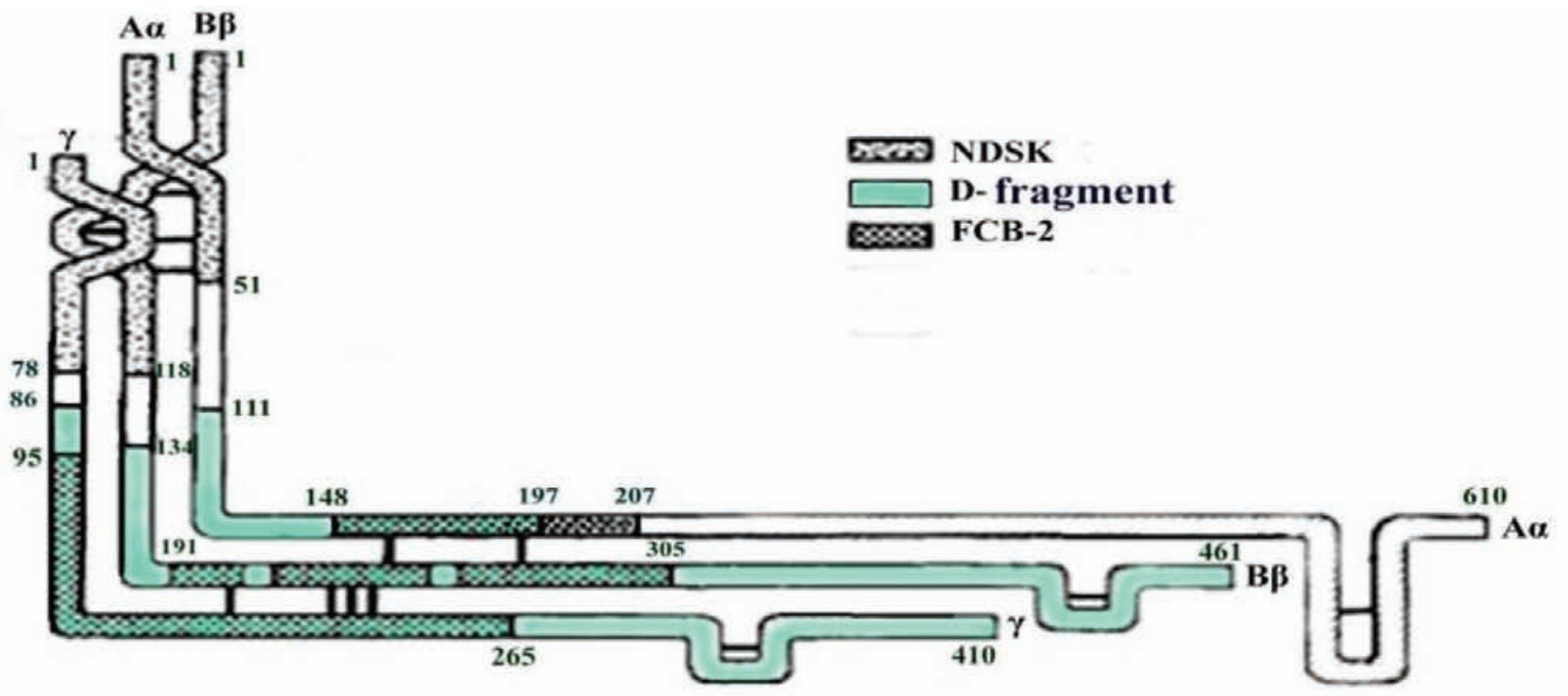

Fig. 3. Scheme of one-half of the fibrinogen molecule (modified from Gardlund [17]). Fragments of chains that belong to the D-fragment are shown in greenish-blue and the cyanogen bromide fragments NDSK and FCB-2 are shaded in two distinct ways (see key above figure), edges of the sequences are marked by the numbers of the amino acid residues. Disulfide bonds are shown as thick dark lines between the chains

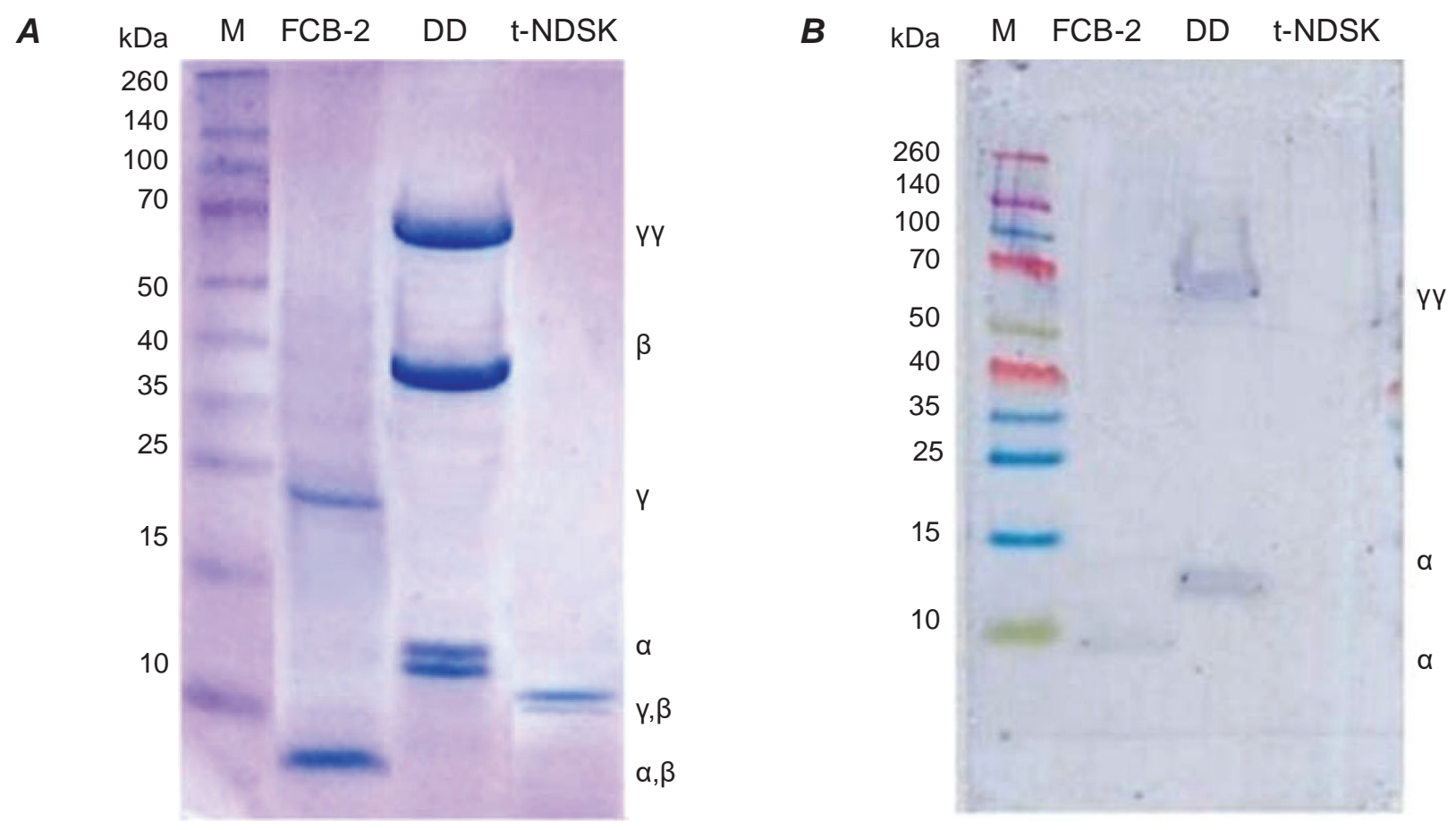

Fig. 4. A - Electrophoregram of DD-fragment of fibrin and cyanogen bromide fibrin fragment FCB-2 and $t$-NDSK reduced by $\beta$-mercaptoethanol. DD-fragment of fibrin is used as a control. $\boldsymbol{B}$ - Western blot image of polypeptide chains of these fragments, to which $K 5$ binds. In both panels, the leftmost lane shows markers of 10-260 kDa (M) 
separated by their ability to bind the immobilized $\mathrm{K} 5$, and then all studied peptides were characterized by MALDI-TOF analysis.

The isolated $\alpha$-chain was obtained by preparative SDS-PAGE. Preliminarily, the disulfide bonds of the D fragment were reduced, then the SH-groups were alkylated. From each $2.0 \mathrm{mg}$ of the D-fragment, we obtained $0.3 \mathrm{mg}$ of $\alpha$-chain. It was hydrolyzed by trypsin at a 1:25 mass ratio of enzyme : substrate at $\mathrm{pH}$ 9.5. The hydrolysate was applied to a $1.4 \mathrm{ml}$ column with K5-Sepharose 4B, containing $0.6 \mathrm{mg}$ of immobilized protein. Rechromatography was performed three times for depletion of the peptides affine to $\mathrm{K} 5$, after which the column was washed with $0.5 \mathrm{M} \mathrm{NaCl}$ in $0.05 \mathrm{M} \mathrm{Na}$-phosphate buffer (pH 7.4), peptides specifically bound to $\mathrm{K} 5$ were eluted with $0.25 \mathrm{M}$ 6-AHA. As a result, $24 \mu \mathrm{g}$ of peptides with affinity for $\mathrm{K} 5$ and $230 \mu \mathrm{g}$ of peptides that are not adsorbed on the affinity sorbent were obtained. The obtained tryptic peptides were analyzed by massspectrometry. The results are given in the Table and Fig. 5. The Table presents tryptic peptides of the $\alpha$-chain of the D-fragment of fibrin, which do not show affinity for K5. There are 11 arginine residues and 9 lysine residues within the studied sequence of $\alpha$ Val111-Arg197 of the D-fragment. In the Table, the arginine and lysine residues located at the C-terminus or inside the tryptic peptides are marked in red.

As expected, peptides having positively charged amino acid residues at the C-terminus did not interact with K5. However, a number of peptides with lysyl and arginyl side radicals do not show affinity for K 5 as well. Interestingly, the tryptic peptide 192Asp - 199Arg, which includes Arg197, was found among them. That is, the location of Arg197 in so-called "proline brackets" (195Pro-203Pro) does not give it the advantage to interact with the K5. Besides, the presence of peptides 192Asp-199Arg, 192Asp-197Arg and 177Asp-197Arg in trypsin hydrolysate suggests that plasmin hydrolysis of fibrin results in a D-fragment formation, whose C-terminal amino acid of the $\alpha$-chain can be equally likely 197Arg or 199Arg. Only two peptides, specifically bound to K5-Sepharose, were eluted with $0.25 \mathrm{M}$ 6-AHA, e.g. 168Ala-176Lys and 172Glu-183Lys. Their mass spectra are presented in Fig. 5. They are referred to as "peptides with a possible one missed cleavage", which corresponds to 171Arg and 176Lys.

It should be noted that the tryptic peptides 163Gly - 171Arg and 172Glu - 176Lys, which contain 171Arg and 176Lys on the C-terminus, respec- tively, do not bind to immobilized K5. Thus, we obtained data that directly indicate that 171Arg and/or 176Lys at polypeptide $\alpha$-chains of fibrin D-fragments are involved in binding to Glu-plasminogen K5. It can be argued that the binding site for Glu-plasminogen, that is complementary to ligand binding site of $\mathrm{K} 5$, is located within sequence A $\alpha 168 \mathrm{Ala}-183 \mathrm{Lys}$ in a weakly structured loop between two supercoils in the $\alpha$-chain of D-fragment of the fibrin(ogen) molecule. The relative positions of 516Asp and 518Asp in the ligand binding site of $\mathrm{K} 5$ and the 171Arg and 176Lys of the $\alpha$-chain of the D-fragment are shown in Fig. 6.

Fig. 7 presents a ribbon scheme of the fibrin(ogen) molecule D-fragment. All three polypeptide chains $-\alpha, \beta$ and $\gamma$, which are part of the $\mathrm{D}$-fragment, in their $\mathrm{N}$-terminus have the structure of the $\alpha$-helix. Beyond the peripheral disulfide node, the $\beta$ - and $\gamma$-polypeptide chains form C-terminal globular $\beta$ - and $\gamma$-modules, while the $\alpha$-chain turns in the opposite direction. After a short weakly structured section, it regains the $\alpha$-helical structure and exits the D-fragment. The black color in the scheme indicates the Aa148-160 sequence, which has the known plasminogen binding site complementary to the LBS of K1-3. The arrow points the position of 171Arg and 176Lys responsible for K5 binding. It can be seen that the fragments, which have binding sites for plasminogen K1-3 and K5, are located in the $\mathrm{D}$-fragment near to each other.

It is hypothesized that interaction of Glu-plasminogen kringle 5 with $\alpha$ Arg171/Lys176 of fibrin leads to the zymogen molecule acquiring an open conformation, which allows K1-3 binding to nearby $\alpha$ Lys148-Ser160 sequence, thus presenting the activation loop for tissue activator cleaving Arg161Val162 peptide bond of plasminogen to form active plasmin. This two-center interaction of plasminogen with fibrin is a necessary condition for zymogen activation.

The obtained novel data on the localization of binding sites of plasminogen $\mathrm{K} 5$ in the polypeptide chains of the fibrinogen D-domains expand our understanding of the functional importance of conformational peculiarities of fibrinogen and plasminogen molecular interactions during fibrinolysis. Our findings are related to the fundamental haemostasis study, which has a potential applied significance in targeting pharmacorrection of fibrinolysis dysfunction and various cardiovascular diseases. 
Tryptic peptides of the $\alpha$-chain of the D-fragment of fibrin(ogen) molecule, which exhibit no affinity to kringle 5

\begin{tabular}{|c|c|c|c|}
\hline \multicolumn{2}{|c|}{ Arg } & \multicolumn{2}{|c|}{ Lys } \\
\hline at the C-terminus & within & at the C-terminus & within \\
\hline \multicolumn{2}{|c|}{$116 \mathrm{R}$} & \multicolumn{2}{|c|}{$123 K$} \\
\hline & 111VSEDLRSR118 & & 117SRIEVLKR124 \\
\hline \multicolumn{2}{|c|}{$118 \mathrm{R}$} & & 119 IEVLKR124 \\
\hline 111VSEDLRSR118 & 117SRIEVLKR124 & \multicolumn{2}{|c|}{$125 \mathrm{~K}$} \\
\hline \multicolumn{2}{|c|}{$124 \mathrm{R}$} & & $\begin{array}{c}\text { 125KVIEKVQHIQLLQK } \\
138\end{array}$ \\
\hline 117SRIEVLKR124 & & \multicolumn{2}{|c|}{$129 \mathrm{~K}$} \\
\hline 119 IEVLKR124 & & & $\begin{array}{c}\text { 125KVIEKVQHIQLLQK } \\
138\end{array}$ \\
\hline \multicolumn{2}{|c|}{$141 \mathrm{R}$} & \multicolumn{2}{|c|}{$138 \mathrm{~K}$} \\
\hline & 139NVRAQLVDMKR149 & $\begin{array}{c}\text { 125KVIEKVQHIQLLQK } \\
138\end{array}$ & \\
\hline \multicolumn{2}{|c|}{$149 \mathrm{R}$} & 130VQHIQLLQK138 & \\
\hline 139NVRAQLVDMKR149 & $\begin{array}{c}\text { 142AQLVDMKRLEVDI } \\
\text { DIKIR159 }\end{array}$ & \multicolumn{2}{|c|}{$148 \mathrm{~K}$} \\
\hline \multicolumn{2}{|c|}{$159 \mathrm{R}$} & & 139NVRAQLVDMKR149 \\
\hline $\begin{array}{l}\text { 142AQLVDMKRLEVDID } \\
\text { IKIR159 }\end{array}$ & 158IRSCR162 & & $\begin{array}{c}\text { 142AQLVDMKRLEVDI } \\
\text { DIKIR159 }\end{array}$ \\
\hline \multicolumn{2}{|c|}{$162 \mathrm{R}$} & \multicolumn{2}{|c|}{$157 \mathrm{~K}$} \\
\hline 158IRSCR162 & 160SCRGSCSR167 & & $\begin{array}{c}\text { 142AQLVDMKRLEVDID } \\
\text { IKIR159 }\end{array}$ \\
\hline \multicolumn{2}{|c|}{$167 \mathrm{R}$} & \multicolumn{2}{|c|}{$176 \mathrm{~K}$} \\
\hline 160SCRGSCSR167 & 163GSCSRALAR171 & 172EVDLK176 & \\
\hline \multicolumn{2}{|c|}{ 171R } & \multicolumn{2}{|c|}{$183 \mathrm{~K}$} \\
\hline 163GSCSRALAR171 & & \multirow{2}{*}{ 177DYEDQQK183 } & $\begin{array}{l}\text { 177DYEDQQK } \\
\text { QLEQVIAK191 }\end{array}$ \\
\hline \multicolumn{2}{|c|}{$197 \mathrm{R}$} & & $\begin{array}{c}\text { 177DYEDQQKQLEQVIA } \\
\text { KDLLPSR197 }\end{array}$ \\
\hline $\begin{array}{l}\text { 177DYEDQQKQLEQVIA } \\
\text { KDLLPSR197 }\end{array}$ & \multirow{2}{*}{ 192DLLPSRDR199 } & \multicolumn{2}{|c|}{$191 \mathrm{~K}$} \\
\hline 192DLLPSR197 & & $\begin{array}{l}\text { 177DYEDQQK } \\
\text { QLEQVIAK191 }\end{array}$ & 177DYEDQQKQLEQVIA \\
\hline \multicolumn{2}{|c|}{$199 \mathrm{R}$} & \multirow{2}{*}{ 184QLEQVIAK191 } & KDLLPSR 197 \\
\hline 192DLLPSRDR199 & & & \\
\hline
\end{tabular}



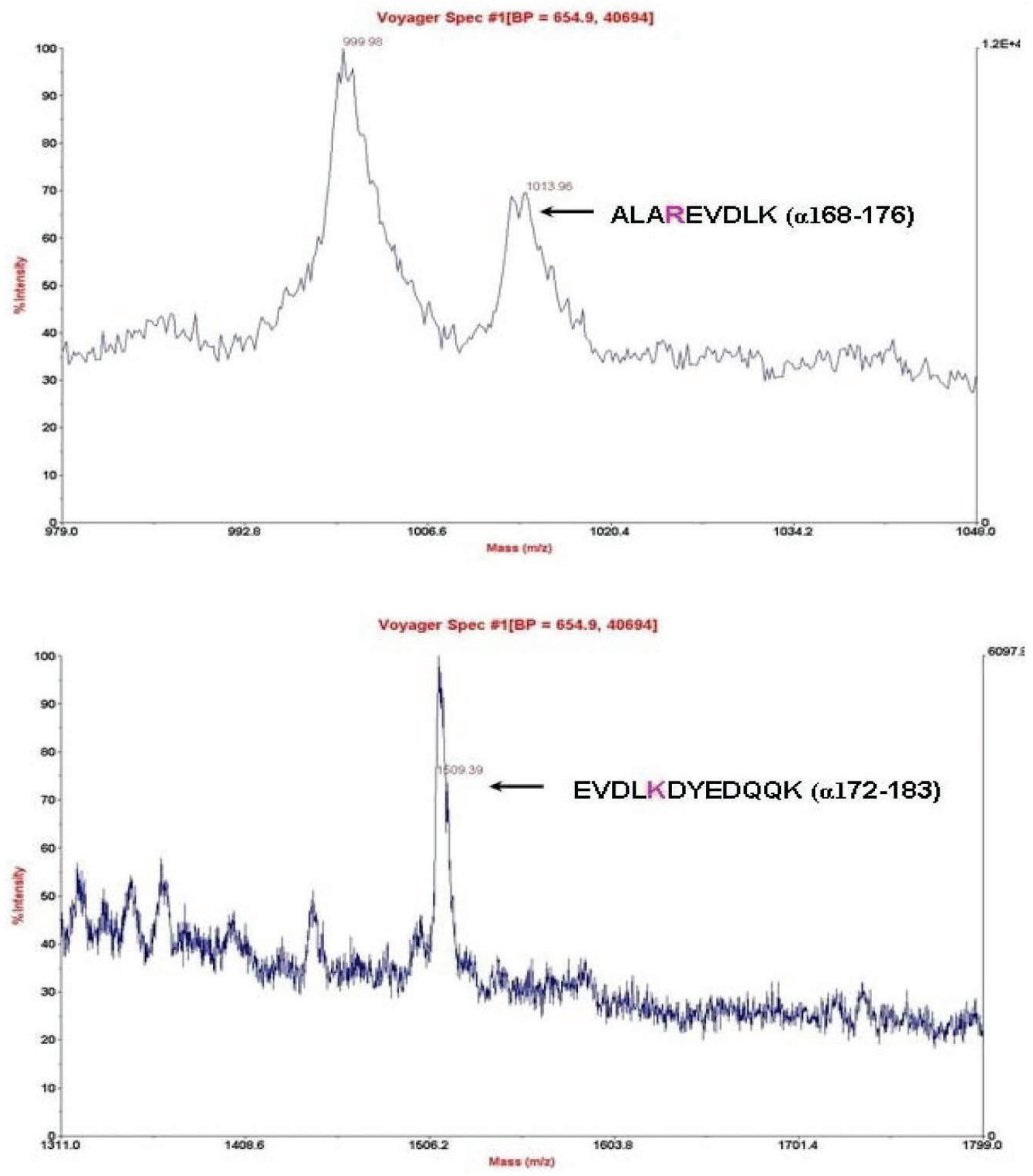

Fig. 5. Mass spectra of tryptic peptides of the $\alpha$-chain of the fibrin D fragment that bind to immobilized K5. The arrows indicate the only two peptides identified that were specifically bound to kringle 5-Sepharose $4 B$. $K$-lysine, $R$ - arginine 


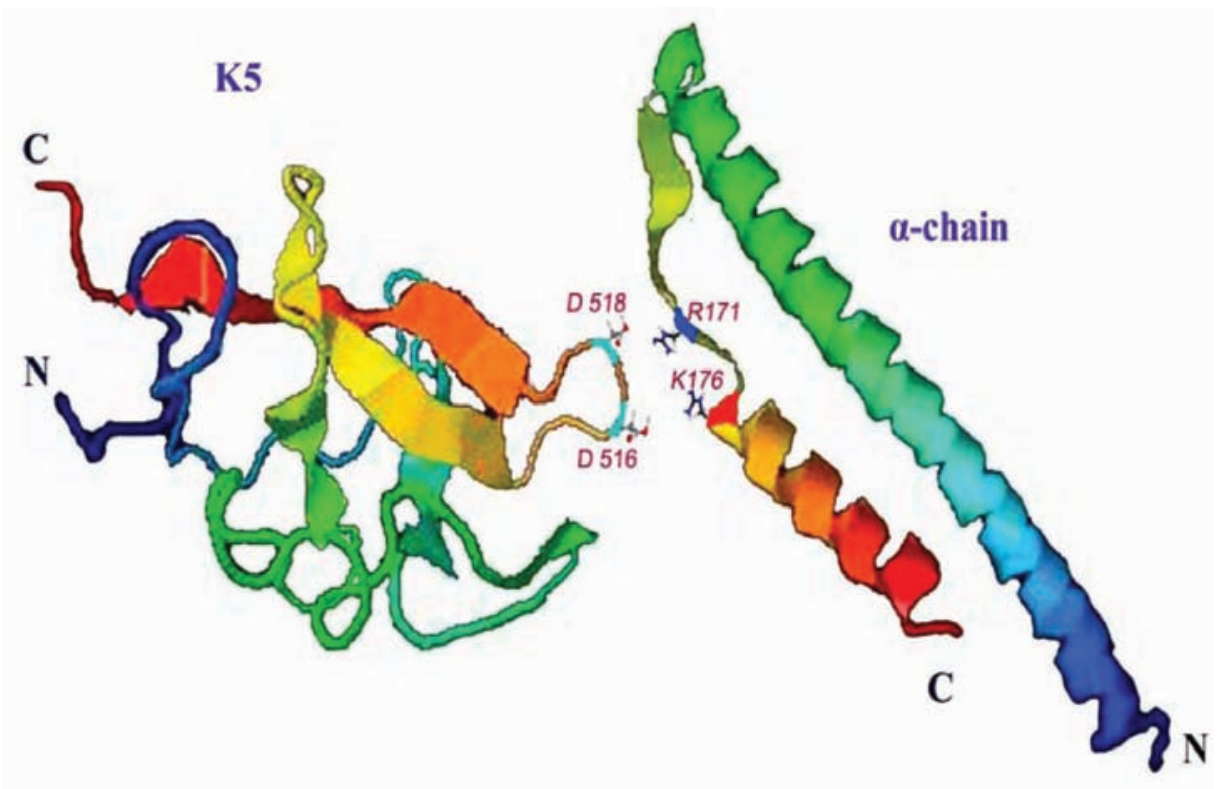

Fig. 6. The superposition of the $\alpha$-chain of the fibrin(ogen) D-fragment (PDB ID: $1 F Z C$ ) and plasminogen K5 (PDB ID: 2KNF) with the corresponding amino acid residues 516Asp and 518Asp of the anion center of K5, and $\alpha 171 \mathrm{Arg}$ and $\alpha 176$ Lys of the K5 binding site of the D-fragment

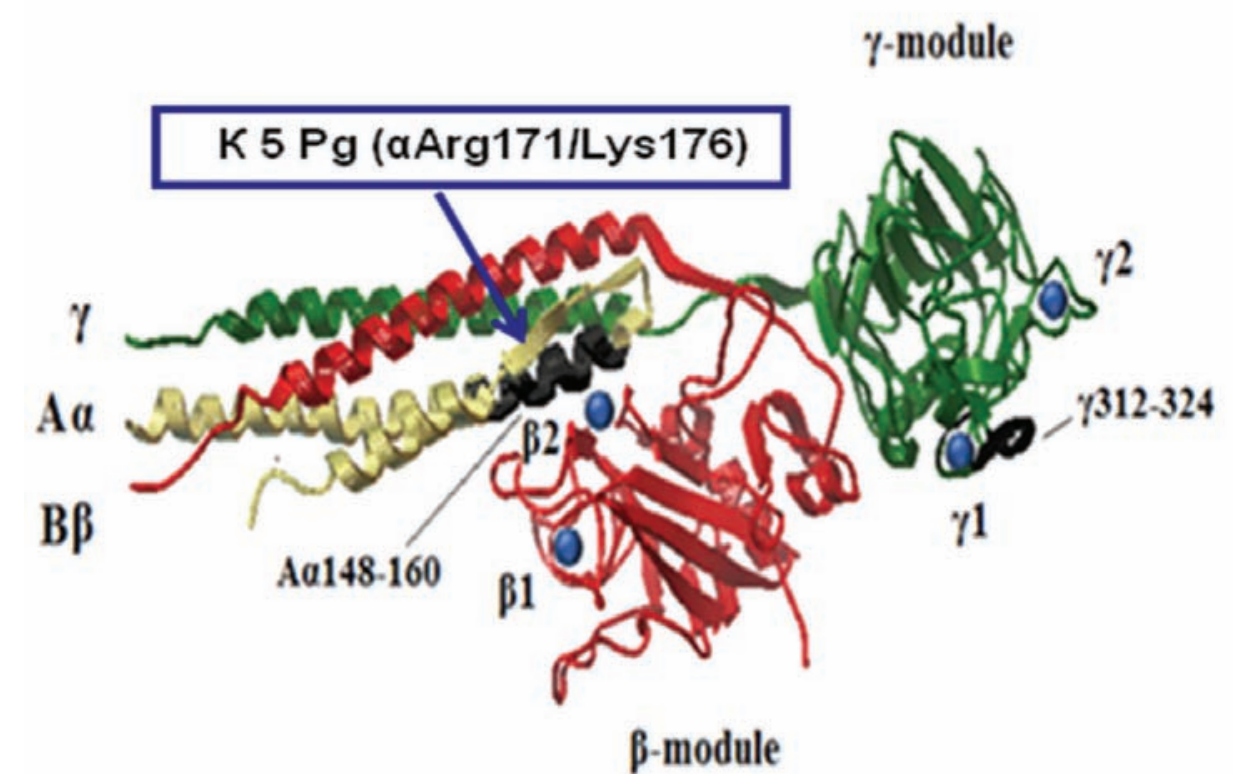

Fig. 7. Ribbon scheme of the fibrin(ogen) D-fragment (PDB ID: 1FZC). Sequence A $148-160$ is shown in black, arrow indicates the location of $171 \mathrm{Arg}$ and 176Lys, to which K5 binds

Conflict of interest. Authors have completed the Unified Conflicts of Interest form at http://ukrbiochemjournal.org/wp-content/uploads/2018/12/coi disclosure.pdf and declare no conflict of interest.
The study was funded by the National Academy of Sciences of Ukraine (State Registration No. 0118U000377). 
Acknowledgements. We thank Cedars-Sinai Medical Center's International Research and Innovation in Medicine Program and the Association for Regional Cooperation in the Fields of Health, Science and Technology (RECOOP HST) Association for their support of our organization as a participating Cedars-Sinai Medical Center - RECOOP Research Center (CRRC).

\section{ІДЕНТИФІКАЦІЯ ДІЛЯНКИ ЗВ'ЯЗУВАННЯ КРИНГЛА 5 ПЛАЗМІНОГЕНУ В $\alpha$-ЛАНЦЮЗІ D-РЕГІОНА ФІБРИН(ОГЕН)У}

\section{Л. Г. Капустяненко, Т. В. Гриненко,}

А. В. Ребрієв, О. І. Юсова, А. О. Тихомиров

$$
\begin{aligned}
& \text { Інститут біохімії ім. О. В. Палладіна } \\
& \text { НАН України, Київ; } \\
& \text { e-mail: kapustyanenko@biochem.kiev.ua }
\end{aligned}
$$

Взаємодія Glu-плазміногену 3 фібрином, опосередкована п'ятим кринглом молекули зимогену, є тригером його активації та ініціації фібринолізу, однак, сайт зв'язування крингла 5 на фібрині залишається невизначеним. Метою роботи було ідентифікувати ділянку в D-фрагменті молекули фібрин(оген) y, що містить сайт, комплементарний лізинзв'язувальному сайту крингла 5. У роботі досліджено взаємодію крингла 5 плазміногену 3 поліпептидними ланцюгами $\mathrm{D}$-фрагментів фібрину та бромціанових фрагментів FCB-2 та t-NDSK. Показано, що крингл 5 специфічно зв'язується $3 \alpha$ - і $\gamma$-ланцюгами D-фрагмента та $\alpha$-ланцюгом FCB-2. Одержано триптичні пептиди $\alpha$-ланцюга $\mathrm{D}$-фрагмента, які розділено за їх афінністю до іммобілізованого крингла 5, та мас-спектри всіх досліджуваних пептидів. Встановлено, що критичними амінокислотними залишками $\alpha$-ланцюга D-фрагмента, що забезпечують взаємодію з кринглом 5, є $\alpha 171 \mathrm{Arg}$ та/ або a176Lys. Показано, що сайт зв'язування Glu-плазміногену, комплементарний лізинзв'язувальному сайту крингла 5, міститься в межах послідовності Aa168Ala-183Lys, яка розташована у слабкоструктурованій петлі між двома суперспіральними ділянками $\alpha$-ланцюга D-регіона молекули фібрин(оген)y.

К л ю ч о в і с л о в а: плазміноген, крингл 5 , фібрин(оген), сайти зв'язування, $\alpha$-ланцюг D-фрагмента фібрину, фібриноліз.

\section{References}

1. Lijnen HR. Elements of the fibrinolytic system. Ann N Y Acad Sci. 2001; 936(1): 226-236.

2. Doolittle RF. Searching for differences between fibrinogen and fibrin that affect the initiation of fibrinolysis. Cardiovasc Hematol Agents Med Chem. 2008; 6(3): 181-189.

3. Ponting CP, Marshall JM, CederholmWilliams SA. Plasminogen: a structural review. Blood Coagul Fibrinolysis. 1992; 3(5): 605-614.

4. Aisina RB, Mukhametova LI. Structure and functions of plasminogen/plasmin system. Bioorg Khim. 2014; 40(6): 642-657. (In Russian).

5. Miles LA, Parmer RJ. Plasminogen receptors: the first quarter century. Semin Thromb Hemost. 2013; 39(4): 329-337.

6. Tykhomyrov AA, Shram SI, Grinenko TV. The role of angiostatins in diabetic complications. Biochemistry (Mosc). Suppl. Series B Biomed. Chem. 2014; 8(2): 94-107.

7. Cockell CS, Marshall JM, Dawson KM, Cederholm-Williams SA, Ponting CP. Evidence that the conformation of unliganded human plasminogen is maintained via an intramolecular interaction between the lysine-binding site of kringle 5 and the N-terminal peptide. Biochem J. 1998; 333(Pt 1): 99-105.

8. Marshall JM, Brown AJ, Ponting CP. Conformational studies of human plasminogen and plasminogen fragments: evidence for a novel third conformation of plasminogen. Biochemistry. 1994; 33(12): 3599-3606.

9. Law RHP, Abu-Ssaydeh D, Whisstock JC. New insights into the structure and function of the plasminogen/plasmin system. Curr Opin Struct Biol. 2013; 23(6): 836-841.

10. Miles LA, Castellino FJ, Gong Y. Critical role for conversion of Glu-plasminogen to Lys-plasminogen for optimal stimulation of plasminogen activation on cell surfaces. Trends Cardiovasc Med. 2003; 13(1): 21-30.

11. Iusova EI, Savchuk OV, Rybachuk VN. Conversion of Glu-plasminogen to Lys-plasminogen on the surface of platelet cell surface. Coll Sci. Articles "Current problems in biochemistry" I Belarusian Biochem. Congr. 2016; 2: 105-111. (In Russian).

12. Thorsen S, Müllertz S, Suenson E, Kok P. Sequence of formation of molecular forms of plasminogen and plasmin-inhibitor complexes in plasma activated by urokinase or tissue-type 
plasminogen activator. Biochem J. 1984; 223(1): 179-187.

13. Wu HL, Chang BI, Wu DH, Chang LC, Gong CC, Lou KL, Shi GY. Interaction of plasminogen and fibrin in plasminogen activation. $J$ Biol Chem. 1990; 265(32): 19658-19664.

14. Grinenko TV, Tret'iachenko VG, Kudinov SA, Medved' LV. Plasminogen-binding centers of molecules of fibrinogen, fibrin and products of their proteolysis. Biokhimiia. 1987; 52(10): 17321739. (In Russia).

15. Taran LD, Makogonenko EM. The effect of kringles $\mathrm{K} 1-3, \mathrm{~K} 4$ and $\mathrm{K} 5$ on lysis of fibrin clots caused by the activation of Glu- and Lysplasminogen by a tissue activator. Ukr Biokhim Zhurn. 1989; 61(4): 31-36. (In Russian).

16. Voskuilen $M$, Vermond A, Veeneman GH, van Boom JH, Klasen EA, Zegers ND, Nieuwenhuizen W. Fibrinogen lysine residue A alpha 157 plays a crucial role in the fibrininduced acceleration of plasminogen activation, catalyzed by tissue-type plasminogen activator. J Biol Chem. 1987; 262(13): 5944-5946.

17. Lezhen TI, Kudinov SA, Medved' LV. Plasminogen-binding site of the thermostable region of fibrinogen fragment D. FEBS Lett. 1986; 197(1-2): 59-62.

18. Varetska TV. Microgeterogeneity of fibrinogen. Cryofibrinogen. Ukr Biokhim Zhurn. 1960; 32: 13-24.

19. Grinenko T. V., Rybachuk V. N., Iatsenko T. A., Kapustianenko L. G. Plasminogen activation by tissue-type activator on DD-fragments of fibrin and Factor XIIIa-cross-linked fibrinogen. Coll. Sci. Articles "Current problems in biochemistry" I Belarusian Biochem. Congr. 2016; 1: 72-77. (In Russian).

20. Pozdnjakova TM, Musjalkovskaja AA, Ugarova TP, Protvin DD, Kotsjuruba VN. On the properties of fibrin monomer prepared from fibrin clot with acetic acid. Thromb Res. 1979; 16(1-2): 283-288.

21. Haverkate F, Timan G. Protective effect of calcium in the plasmin degradation of fibrinogen and fibrin fragments D. Thromb Res. 1977; 10(6): 803-812.

22. Lugovskoy EV, Gritsenko PG, Kapustianenko LG, Kolesnikova IN, Chernishov VI, Komisarenko SV. Functional role of B $\beta$-chain NH2-terminal fragment in fibrin polymerization process. FEBS J. 2007; 274(17): 4540-4549.
23. Deutsch DG, MertzET. Plasminogen: purification from human plasma by affinity chromatography. Science. 1970; 170(3962): 1095-1096.

24. Kapustianenko LG, Iatsenko TA, Yusova EI, Grinenko TV. Isolation and purification of a kringle 5 from human plasminogen using $\mathrm{AH}-$ Sepharose. Biotechnologia Acta. 2014; 7(4): 35-42.

25. Kapustianenko LG. Polyclonal antibodies against human plasminogen kringle 5. Biotechnologia Acta. 2017; 10(3): 41-49.

26. Schägger H, Von Jagow G. Tricinesodium dodecyl sulfate-polyacrylamide gel electrophoresis for the separation of proteins in the range from 1 to $100 \mathrm{kDa}$. Anal Biochem. 1987; 66(2): 368-379.

27. Burnette WN. "Western blotting": electrophoretic transfer of proteins from sodium dodecyl sulfate--polyacrylamide gels to unmodified nitrocellulose and radiographic detection with antibody and radioiodinated protein A. Anal Biochem. 1981; 112(2): 195-203.

28. Cavins JF, Friedman M. An internal standard for amino acid analyses: S-beta-(4-pyridylethyl)-Lcysteine. Anal Biochem. 1970;35(2):489-493.

29. Strong DD, Watt KWK, Cottrell BA, Doolittle RF. Amino acid sequence studies on the alpha chain of human fibrinogen. Complete sequence of the largest cyanogen bromide fragment. Biochemistry. 1979; 18(24): 5399-5404.

30. Spraggon G, Everse SJ, Doolittle RF. Crystal structures of fragment D from human fibrinogen and its crosslinked counterpart from fibrin. Nature. 1997; 389(6650): 455-462.

31. Battistel MD, Grishaev A, An SS, Castellino FJ, Llinás M. Solution structure and functional characterization of human plasminogen kringle 5. Biochemistry. 2009; 48(43): 1020810219.

32. Grinenko TV, Kapustianenko LG, Yatsenko TA, Yusova OI, Rybachuk VN. Plasminogen fragments K 1-3 and K 5 bind to different sites in fibrin fragment DD. Ukr Biochem J. 2016; 88(3): 36-45.

33. Nieuwenhuizen W. Fibrin-mediated plasminogen activation. Ann N Y Acad Sci. 2001; 936: 237246.

34. Verevka SV, Grinenko TV. Pseudo-functional interactions of plasminogen: molecular mechanisms and pathologic appearance. In: Advances in Medicine and biology. Nova Science Publishers, Inc.Ed: Leon V. Berhardt. 2011; 34: 35-61. 